УДК 347.440 .51

DOI https://doi.org/10.32849/2663-5313/2020.3.04

Наталія Люльчук,

аспірант кафедри чивільного права і процесу

Національної академії внутрішніх справ

\title{
НЕЯКІСНЕ НАДАННЯ ПРАВНИЧИХ ПОСЛУГ ЯК ПІДСТАВА ЦИВІЛЬНО-ПРАВОВОЇ ВІДПОВІДАЛЬНОСТІ
}

Метою иивільно-правової відповідальності за договором про надання правничої допомоги $\epsilon$ захист сторін зазначеного договору та відновлення їхніх порушених прав, тоді як ї̈ підставою є неналежне виконання або невиконання умов договору про надання правничої допомоги. У цьому контексті особливо гостро постає проблема визначення критеріїв належного виконання правником своїх зобов'язань за договором, а відповідно, якості правничої допомоги. У законодавстві якість надання послуг визначається як відповідність показників якості послуг з технічного обслуговування вимогам нормативних документів. Наукові погляди на якість послуги в иілому можуть бути узагальнені таким визначенням: «якість послуги являє собою ї здатність задовольнити потреби та очікування конкретного споживача». Міжнародний стандарт ISO-900:2015 поняття якості поширює на об'єкт якості, яким може бути не тільки продукт, а й послуги. Властивість об'єкта задовольнити потреби може бути представлена сукупністю його характеристик, які належать до його властивості задовольнити встановлені та передбачувані потреби. Оскільки надання правничої допомоги, змістом якої є надання послуг, - ие певний прочес, то визначити його якість можливо шляхом детальної регламентаиіӥ стадій. У зв'язку із иим у науковій літературі висловлюються думки про те, що суттєву роль у підвищенні якості правничої допомоги може відігравати докладне врегулювання самої процедури надання правничих послуг, встановлення стандартів правничої діяльності, зокрема, шляхом стандартизачії. 3 метою впровадження стандартизачіі послуг з надання правничої допомоги в Україні може бути використаний досвід Великої Британії, який передбачає використання для оцінювання якості правничої допомоги низки критеріїв. Якість правничої допомоги має визначатися як одна з істотних умов ивого договору, в тому числі як невід'ємна характеристика його предмета, що підводить нас до необхідності внесення змін до ЦК України в частині визначення спеиифіки договору про надання правничої допомоги порівняно із загальними нормами, що регулюють питання договорів про надання послуг. Неякісне надання правничих послуг є ознакою неналежного виконання договору про надання правничої допомоги, тож слугує підставою иивільно-правової відповідальності.

Ключові слова: правнича допомога, послуга, якість, сертифікація, послуго надавачі.

Постановка проблеми. Метою цивільноправової відповідальності за договором про надання правничої допомоги є захист сторін зазначеного договору та відновлення їхніх порушених прав, тоді як її підставою є неналежне виконання або невиконання умов договору про надання правничої допомоги. У цьому контексті особливо гостро постає проблема визначення критеріїв належного виконання правником своїх зобов'язань за договором про надання правничої допомоги, а відповідно, якості правничої допомоги.

Стан дослідження. Питання цивільноправової відповідальності за невиконання або неналежне виконання договірних зобов'язань почали активно вивчатися цивілістами ще за радянських часів. Дослідженню питань цивільно-правового регулю- вання надання правничої допомоги приділялася увага у наукових працях С. Борисенка, Є. Васьковського, І. Владімірової, І. Гловацького, А. Джуської, В. Заборовського, В. Личко, М. Кратенка, П. Павліша, В. Попелюшка, О. Святоцького, І. Синяка, А. Титова, I. Токмакова, В. Третьякової, О. Філонова, В. Шкарупи та інших дослідників. При цьому питання підстав цивільно-правової відповідальності, особливо в аспекті неналежного виконання договору 3 точки зору якості надання правничих послуг, наразі лишаються дослідженим недостатньо. Зокрема, як зазначає Н. Грищенко, «розширювальний підхід до підстав і наслідків виникнення професійної відповідальності відповідно до цивільного законодавства з очевидністю висуває і проблему виконання професійних 
зобов'язань або компенсації шкоди, заподіяної особистості або юридичній особі при виконанні цієї професійної діяльності» [1].

Мета статті полягає у дослідженні питань якісного та належного виконання договору про надання правничої допомоги в контексті підстав цивільно-правової відповідальності.

Виклад основного матеріалу. Слід зауважити, що в контексті проблематики цивільно-правової відповідальності за договором про надання правничої допомоги особливо гостро постає проблема визначення критеріїв належного виконання правником своїх зобов'язань за договором про надання правничої допомоги. Отже, вирішуючи питання про наявність підстав цивільно-правової відповідальності виконавця (послугонадавача), необхідно дати оцінку факту невиконання або неналежного виконання договору. Вважаємо, що виконання стороною істотних умов договору передусім і буде характеризувати його належне виконання, а відповідно, порушення цих умов тягтиме за собою цивільно-правову відповідальність. Так, С. Суханов вказує, що в разі неякісного надання правничих послуг «замовник має право, якщо інше не встановлено законом або договором, за своїм вибором вимагати від виконавця: або відповідного зменшення встановленої за надання послуги ціни; або безоплатного надання послуги заново 3 відшкодуванням замовникові завданих простроченням виконання збитків» [2, с. 9]. На думку М. Кратенка, специфіка правової послуги не дозволяє сформулювати в самому договорі про надання правничої допомоги конкретні вимоги до діяльності правника, що ускладнює доведення неналежного виконання зобов'язання [3, с. 28]. 3 цим можна погодитись, однак це не знімає питання щодо якості правничої допомоги та встановлення загальних, найбільш важливих та необхідних критеріїв іï оцінки, оскільки про належне виконання договору про надання правничої допомоги можна говорити тоді, коли він виконаний не лише в повному обсязі, але й якісно. Не випадково у юридичній літературі зазначається, що якість виконання одна 3 істотних умов договору про надання послуг [4, с. 123], а також що якість послуги найважливіша характеристика предмета відповідного договору. Відповідно, вважається, що законом чи іншими нормативними актами можна передбачити обов'язкові вимоги до якості результату надання послуги [5, с. 474]. Зауважимо також, що «якість» в аспекті надання правничої допомоги не тотожна «професійності». I, хоча ст. 59 Конституції
України [6] передбачає право на професійну правничу допомогу, так звана «адвокатська монополія», що склалася на виконання цієї конституційної вимоги, забезпечує лише надання правничої допомоги певною категорією правників, проте не гарантує надання якісної правничої допомоги. Водночас, наприклад, ч. 8 ст. 12 Закону України «Про безоплатну правову допомогу» [7] передбачає, що «адвокат, інший фахівець у відповідній галузі права чи юридична особа приватного права, з якими укладено договір про надання первинної правової допомоги, зобов'язані надавати високоякісну допомогу в обсязі та строки, визначені договором». Так само ч. 4 ст. 22 того ж Закону передбачено, що «адвокат, з яким укладено договір про надання безоплатної вторинної правової допомоги, зобов'язаний надати таку допомогу якісно в обсязі та у строки, визначені договором» [8].

Якщо звернутися до законодавчих визначень, то якість надання послуг визначається як відповідність показників якості послуг 3 технічного обслуговування вимогам нормативних документів [9]. Наукові погляди на якість послуги в цілому можуть бути узагальнені таким визначенням: «якість послуги являє собою іiї здатність задовольнити потреби та очікування конкретного споживача» [10].

Міжнародний стандарт ISO-900:2015 «Системи управління якістю. Словник» поняття якості поширює на об'єкт якості, яким може бути не тільки продукт, а й послуги. Властивість (здатність) об'єкта задовольнити потреби згідно з цим Стандартом може бути представлена сукупністю його характеристик, які належать до його властивості задовольнити встановлені та передбачувані потреби [11].

Якість може оцінюватись шляхом визначення кількісних або якісних характеристики i, відповідно, розглядатися як абстрактна, орієнтована на продукт, орієнтована на споживача, орієнтована на виробництво та орієнтована на створення цінностей [12], проте наведені категорії не дають повного уявлення про сутність якості послуги, тому їх доповнюють, використовуючи критерії якості, за якими споживач виказує своє ставлення до послуги, - надійність, чуйність, безпека, взаєморозуміння зі споживачем та очевидність [13]. Надійність визначається наданням послуги у зазначені терміни, з першого разу та за узгодженою ціною. Чуйність визначається прагненням або готовністю виконавця (або персоналу юридичної особипослугонадавача) до своєчасного надання послуги, а також реагування на терміновість 
виконання замовлення. Безпека стосується знань,компетенції,навичок, професіоналізму, ввічливості та здатності виконавця викликати та заслужити довіру виконавця. Взаєморозуміння зі споживачем визначається як турбота та персоніфікована увага до замовника. Очевидність пов'язана 3 фізичним підтвердженням послуги і включає засоби обслуговування, зовнішність виконавця, інструмент або обладнання, за допомогою якого надається послуга, тощо [14].

Незважаючи на досить абстрактне уявлення про якість послуг в цивілістичній доктрині, І. Утєхін вважає, що у цивільному праві існує презумпція «якості послуги», адже інакше послугоотримувач зазнає порушення своїх прав на надання послуги, яку він замовив. На думку науковця, для уникнення ототожнення із договором підряду під корисним результатом слід розуміти корисний ефект послуги, причому цьому слід розрізняти випадки, коли корисний ефект гарантується і навпаки [15]. Так, договір про надання правничої допомоги передбачає досягнення передусім непредметного результату (за винятком випадків, коли йдеться про складання юридичних документів), але водночас і дуже конкретного, який може виражатися у вирішенні матеріального спору, встановленні факту, що має юридичне значення, тощо. Тож оцінити якість наданої правничої допомоги можна за результатом, який буде досягнуто через деякий час. Якість послуг, що становлять зміст правничої допомоги, залежить від цілої сукупності факторів: професійної компетенції послугонадавача, володіння інформацією про останні зміни у законодавстві, знань основних тенденцій судової практики тощо, а також від того, наскільки правильно клієнт зрозумів і реалізував отриману ним від правника інформацію [15].

У юридичній літературі можна зустріти підхід, за якого оцінка якості послуг (в тому числі й правничих) полягає у характеристиці самого процесу надання послуги та умов її споживання (сервіс послуги), але не результату діяльності виконавця. Наприклад, О. Романець зазначає, що послуги переважно не переслідують досягнення зовні вираженого і віддільного від самого виконавця результату, тому і «критерії якості подібних послуг повинні бути спрямовані на сам процес їх надання» [16]. Дійсно, недосягнення результату не може за загальним правилом розглядатися як неналежне виконання зобов'язання і бути підставою для відмови у виплаті винагороди виконавцю або застосування до нього заходів відповідальності. М. Кротов, аналізуючи радянське законодавство у сфері обслуговування населення, також дійшов висновку про те, що під якістю послуги зазвичай малася на увазі якість процесу обслуговування; при цьому «як детально не були б врегульовані вимоги до якості процесу обслуговування, не можна бути впевненим у якості кінцевого продукту цієї діяльності» [17, с. 51]. Інші автори, навпаки, наполягають на вирішальному значенні досягнення позитивного результату в оцінці якості правничих послуг [18, с. 51]. Разом із тим науковці, які дотримуються цього підходу, вважають, що винесення судом рішення не на користь клієнта не повинно завжди сприйматися як ознака неякісної роботи юриста. Водночас дотримання правил складання позовної заяви та інших офіційних документів, термінів для звернення до суду або інших уповноважених органів є мінімальним стандартом належної якості правничої допомоги. Порушення правником подібних правил має визнаватися достатньою підставою для зниження розміру його гонорару або стягнення з нього збитків.

Слід наголосити, що лише та послуга, яка відповідає умовам договору, здатна задовольнити потреби особи. Це повною мірою стосується й питань надання правничої допомоги. Оскільки послуга - це дія (діяльність), певний процес, то визначити якість цього процесу можливо [15] шляхом детальної регламентації його стадій. У зв’язку із цим у науковій літературі висловлюються думки про те, що суттєву роль у підвищенні якості правничої допомоги може відігравати докладне врегулювання самої процедури надання правничих послуг, встановлення стандартів правничої діяльності, зокрема шляхом ліцензування, сертифікації та стандартизації [19, с. 141-143].

Сьогодні вітчизняне законодавство приділяє питанням стандартизації та ліцензування послуг незначну увагу, що пов'язано із загальнодержавними процесами лібералізації регулювання господарської діяльності. Зокрема, нині ліцензуванню підлягають медичні послуги. Стосовно юридичної практики процедура ліцензування існувала до 2000 року [20], однак більшість науковців, адвокатів і представників органів юстиції скептично оцінювали їі можливості в плані забезпечення якості юридичної допомоги.

Господарський кодекс України містить положення про сертифікацію послуг з метою попередження небезпеки для життя та здоров'я, майна громадян і навколишнього середовища. Під сертифікацією розуміється підтвердження відповідності послуг вимогам стандартів [21]. Отже, законодавець обмежив застосування сертифікації послуг лише критерієм їх небезпеки для суспільства 
і навколишнього середовища. Закон України «Про стандартизацію» [22] передбачає, що метою стандартизації в Україні є забезпечення відповідності об'єктів стандартизації своєму призначенню; керування різноманітністю, застосовність, сумісність, взаємозамінність об'єктів стандартизації; забезпечення раціонального виробництва шляхом застосування визнаних правил, настанов i процедур; забезпечення охорони життя та здоров'я; забезпечення прав та інтересів споживачів; забезпечення безпечності праці; збереження навколишнього природного середовища і економія всіх видів ресурсів; усунення технічних бар'єрів у торгівлі та запобігання їх виникненню, підтримка розвитку і міжнародної конкурентоспроможності продукції. Питання щодо визначення якості послуг частково вирішується у Переліку послуг, що підлягають обов'язковій сертифікації в Україні. Однак натепер це зазначено лише щодо готельних послуг і послуг харчування. Ще одним прикладом є Наказ Міністерства юстиції України від 31.08.2009 р. № 1555/5 «Про затвердження стандартів надання адміністративних послуг», яким визначено дванадцять стандартів, серед яких стандарти для надання адміністративної послуги зі здійснення реєстрації адвокатських об'єднань, політичних партій, благодійних організацій, засобів масової інформації тощо [23]. Звісно, наведені нормативно-правові акти не регламентують питання надання правничої допомоги, однак на підставі їх існування можна стверджувати, що, незважаючи на нематеріальний характер послуги взагалі, контроль за її якістю цілком можливий і передбачає встановлення відповідності діяльності щодо надання послуги іï суті, меті для задоволення потреб її споживача шляхом перевірки всього процесу надання правничої допомоги. Якість послуги за таких умов - це відповідність її назві, критеріям, що містяться у договорі, нормативному акті чи звичаях ділового обігу [15], що в повному обсязі стосується і правничих послуг, які становлять зміст надання правничої допомоги. Більшою мірою, ніж діяльність правників у цілому, стандартизована діяльність адвокатів, отже, вчинення адвокатом проступків, прямо перерахованих у Законі України «Про адвокатуру та адвокатську діяльність» [8] або Кодексі професійної етики [24], або невідповідність його дій визначеним правилам можуть розцінюватись як підстава притягнення адвоката не лише до дисциплінарної, але й до цивільно-правової відповідальності. Водночас доведення клієнтом неякісної роботи правника за відсутності безпосеред- нього порушення будь-яких процесуальних правил або професійних стандартів ускладнюється усталеним уявленням про свободу адвоката у виборі стратегії і тактики захисту у конкретній справі.

Вважаємо, що 3 метою впровадження стандартизації послуг з надання правничої допомоги в Україні може бути використаний досвід Великої Британії [25; 26], який передбачає використання для оцінювання якості правничої допомоги таких критеріїв: доступ до правничих послуг (планування надання послуг, надання доступної інформації про послуги, безоплатність правничих послуг, заборона на дискримінацію у наданні послуг); обсяг послуг, в тому числі можливість спрямування до інших послугонадавачів, якщо цього вимагають інтереси клієнта; управління діяльністю 3 надання правничої допомоги (належні процедури фінансового і кадрового менеджменту у юридичних особах, що надають правничу допомогу); задоволення потреб і запитів клієнтів (надання інформації клієнтам, конфіденційність і захист персональних даних клієнта, гарантії якості правничої допомоги у випадках, коли для надання окремих правничих послуг залучаються треті особи); система покращення якості правничої допомоги (розробка і впровадження служби прийому скарг та відгуків клієнтів, постійне вдосконалення систем управління якістю тощо).

\section{Висновки}

Якість правничої допомоги має визначатися як одна 3 істотних умов договору про надання правничої допомоги, в тому числі як невід'ємна характеристика його предмета, що підводить нас до необхідності внесення змін до ЦК України (доповнення окремою главою) в частині визначення специфіки договору про надання правничої допомоги порівняно із загальними нормами, що регулюють питання договорів про надання послуг. При цьому якість правничої допомоги становить зумовлену професійною компетенцією правника-послугонадавача категорію, що включає в себе рівень володіння ним законодавством, основними тенденціями судової практики, навичками складання процесуальних документів, передбачає максимальну їх реалізацію для цілей договору про надання правничої допомоги, а також характеризується надійністю, чуйністю, безпекою, взаєморозумінням 3 клієнтом та очевидністю. Своєю чергою, неякісне надання правничих послуг є ознакою неналежного виконання договору про надання правничої допомоги, тож слугує підставою цивільно-правової відповідальності. 


\section{Список використаних джерел:}

1. Грищенко Н. Б. Профессиональная ответственность: основания и последствия се возникновения. Страховое дело. 2004. № 1. С. 6

2. Гражданское право : в 2-х т. Т. 2. Полутом $2 /$ отв. ред. Е. Суханов. Москва, 2000. 704 с.

3. Кратенко М. В. Договор об оказании юридической помощи в современном гражданском законодательстве : дисс. ... канд. юрид. наук. Томск, 2005. 275 с.

4. Цивільне право України: Академічний курс : підручник : у 2-х т. Київ : Ін Юре, 2003. Т. 2 : Особлива частина. $406 \mathrm{c}$.

5. Договірне право України. Особлива частина : навчальний посібник. Київ : Юрінком Інтер, 2009. 1199 c.

6. Конституція України від 28.06.1996 р. URL: zakon5.rada.gov.ua/laws/ show/254k/96-вp.

7. Про безоплатну правову допомогу : Закон України від 02.06.2011 № 3460-VI. URL: https:// zakon.rada.gov.ua/go/3460-17 (дата звернення: 02.03.2020)

8. Про адвокатуру та адвокатську діяльність : Закон України від 05.07.2012 № 5076-VI. URL: https://zakon.rada.gov.ua/laws/ show/5076-17 (дата звернення: 02.03.2020).

9. Про затвердження Порядку відшкодування збитків, завданих газопостачальному або газорозподільному підприємству внаслідок порушення споживачем природного газу Правил надання населенню послуг з газопостачання, а також споживачеві природного газу внаслідок порушення газопостачальним або газорозподільним підприємством Правил надання населенню послуг з газопостачання : Постанова Нацкоменергетики від 28.10.2014 № 184. URL: https:// zakon.rada.gov.ua/laws/show/z0008-15 (дата звернення: 12.03.2020)

10. Весперіс С. 3. Особливості формування i управління якістю послуг. URL: https:// essuir.sumdu.edu.ua/bitstream/123456789/ 29486/3/Vesperis quality.pdf (дата звернення: 02.03.2020).

11. Міжнародний стандарт ISO-900:2015 «Системи управління якістю. Словник». URL: https:// khoda.gov.ua/image/catalog/files/\%209000.pdf. (дата звернення: 02.02.2020).

12. Хаксевер К., Рендер Б., Рассел Р., Мендрик Р. Управление и организация в сфере услуг. СПб.: Питер, 2002.752 с

13. Всеобщее управление качеством : учебник для вузов. Москва : Радио и связь, 2001. 600 с
14. Пащук О. В. Маркетинг послуг: стратегічний підхід. Київ, 2005. 558 с.

15. Утехін І.Б. Якість послуг за договором в цивільному праві. URL: http:/ irbis-nbuv.gov.ua/cgi-bin/irbis_nbuv/cgiirbis_64. exe? C $21 \mathrm{COM}=2 \& \mathrm{I} 21 \mathrm{DBN}=\mathrm{UJRN} \& \mathrm{P} 21 \mathrm{D}$ $\mathrm{B} \mathrm{N}=\mathrm{U} J \mathrm{R}$ N \& M A G E F I L E DOWNLOAD $=1 \&$ Image file $\overline{\text { name }}=\mathrm{PDF}$ Unzap_2010_4_13.pdf. (дата звернення: 02.02.2020).

16. Романец Ю. В. Система договоров в гражданском праве России. Москва, 2005. С. 399-400.

17. Кротов М. В. Обязательство по оказанию услуг в советском гражданском праве : дисс. .. канд. юрид.наук: 12.00.03. Ленинград, 1989. 123 с.

18. Козлова Н. В. Договор возмездного оказания правовых услуг. Законодательство. 2002 № 4. С. 51 .

19. Салчак А. А. Договор об оказании юридических услуг: особенности гражданско-правовой ответственности его участников : дисс. ... канд. юрид. наук. Москва, 2006. 200 с.

20. Комментарий относительно лицензирования юридической практики. URL: https:// www.legalalliance.com.ua/rus/publikacii/ kommentarij-otnositelno-licenzirovania-uridiceskojpraktiki (дата звернення: 04.03.2020).

21. Господарський кодекс України. URL: https://zakon.rada.gov.ua/laws/show/436-15 (дата звернення: 03.03.2020)

22. Про стандартизацію : Закон України від 05.06 .2014

№ 1315-VII. URL: https://zakon.rada.gov.ua/ laws/show/ 1315-18 (дата звернення: 12.03.2020).

23. Про затвердження стандартів надання адміністративних послуг : наказ Міністерства юстиції України від 31.08.2009 р. № 1555/5. URL: https://zakon.rada. gov.ua/ laws/show/ v1555323-09 (дата звернення: 12.02.2020).

24. Правила адвокатської етики : затверджені Звітно-виборним з'їздом адвокатів України від 09.06.2017. URL: https://zakon.rada.gov.ua/ rada/ show/n0001891-17 (дата звернення: 12.02.2020).

25. Specialist Quality Mark Standard. URL: http://www.justice.gov.uk/legal-aid/qualityassurance/quality-mark.

26. Граматиков М. Качество и стандарты бесплатной юридической помощи, оказываемой в порядке еx officio. Бесплатная юридическая помощь: модель взаимодействия государства и гражданского общества (зарубежный и российский опьт) : сборник докладов. Москва : ООО «Акварель», 2011. 277 с.

The purpose of civil liability for a legal aid agreement is to protect the parties to the said contract and to restore their violated rights, while its basis is the improper performance or non-compliance with the terms of the legal aid contract. In this context, the problem of defining the criteria for the proper fulfillment by a lawyer of his obligations under a legal aid agreement and, accordingly, the quality of legal aid, is particularly acute. In legislation, the quality of service provision is defined as the compliance of the quality of service performance indicators with the requirements of regulatory documents. Scientific views on the quality of the service as a whole can be summarized by the following definition: "quality of service is its ability to meet the needs and expectations of a particular consumer". International Standard ISO-900:2015 the concept of quality extends to a quality object that can be not only a product but also 
a service. The property of an object to meet the needs may be represented by the aggregate of its characteristics that relate to its property to satisfy the identified and foreseen needs. Since the provision of legal assistance, the content of which is the provision of services, is a certain process, it is possible to determine its quality through detailed regulation of the stages. In this regard, the scientific literature expresses the opinion that a detailed regulation of the procedure of rendering legal services, in particular, through standardization, can play a significant role in improving the quality of legal assistance. In order to implement standardization of legal aid services in Ukraine, the experience of the United Kingdom can be used, which involves a number of criteria to evaluate the quality of legal aid. The quality of legal aid should be defined as one of the essential conditions of this contract, including as an integral characteristic of its subject, which leads us to the need to amend the Civil Code of Ukraine in terms of defining the specifics of the legal aid agreement in comparison with the general rules governing the issues of service contracts. In turn, poor legal service provision is a major sign of a misapplication of a legal aid agreement and serves as a basis for civil liability.

Key words: legal assistance, service, quality, certification, service providers. 